\title{
PENGARUH KOMPENSASI TERHADAP KINERJA KARYAWAN
}

\author{
Zuriana ${ }^{1)}$ \\ Andika Rananda ${ }^{1)}$ \\ 1) Institut Informatika dan Bisnis Darmajaya, Lampung \\ zuriana@darmajaya.ac.id, andikarananda16@gmail.com
}

\begin{abstract}
ABSTRAK: Tujuan dari penelitian ini adalah untuk mengetahui pengaruh Kompensasi terhadap Kinerja karyawan di PT Sumber Trada Motor Bandar Lampung. Penelitian ini merupakan jenis penelitian kuantitatif dengan metode penelitian asosiatif. Penelitian ini dilakukan di PT Sumber Trada Motor Bandar Lampung. Teknik pengambilan sampel menggunakan teknik sampel jenuh dan metode analisis data menggunakan regresi linier sederhana dan pengujian hipotesis menggunakan uji t dan uji f. Responden dalam penelitian ini sebanyak 36 (tiga puluh enam) karyawan. Uji persyaratan instrumen dalam penelitian ini menggunakan uji validitas dan uji reliabilitas. Hasil penelitian ini menunjukan bahwa Kompensasi berpengaruh terhadap Kinerja. Artinya semakin baik kompensasi diberikan kepada karyawan maka semakin tinggi pula tingkat kinerja karyawan pada perusahaan.
\end{abstract}

Kata kunci : Kompensasi, Kinerja.

ABSTRACT: The purpose of this study was to determine the effect of Compensation on Performance of employees at PT Sumber Trada Motor Bandar Lampung. This research is a type of quantitative research with associative research methods. This research was conducted at PT Sumber Trada Motor Bandar Lampung. The sampling technique uses saturated sample techniques and data analysis methods using simple linear regression and hypothesis testing using the t test and f test. Respondents in this study were 36 (thirty six) employees. Test the instrument requirements in this study using the validity test and reliability test. The results of this study indicate that Compensation has an effect on Performance. This means that the better compensation is given to employees, the higher the level of employee performance at the company.

Keywords: Compensation, Performance.

\section{PENDAHULUAN}

Sumberdaya manusia merupakan salah satu aset terpenting bagi perusahaan. Peran sumberdaya manusia bagi perusahaan tidak hanya dilihat dari hasil produktivitas kerja tetapi juga dapat dilihat dari kualitas kerja yang dihasilkan, bahkan lebih jauh keunggulan suatu perusahaan juga ditentukan oleh keunggulan daya saing manusianya bukan ditentukan lagi oleh sumberdaya alamnya. semakin kuat pengetahuan (knowledge) dari sumberdaya manusia suatu perusahaan akan semakin kuat daya saing perusahaan tersebut.

PT Sumber Trada Motor adalah perusahaan yang bergerak dibidang kendaraan roda dua dengan merek Kawasaki. Perusahaan ini merupakan satu satunya dealer yang ada di kota Bandar Lampung yang memiliki 3 cabang dealer. Perusahaan ini dipercaya bisa menjual produk Kawasaki diwilayah Bandar Lampung. 
Kinerja karyawan pada perusahaan merupakan fondasi dasar yang harus dibangun, dijaga dan di kembangkan dalam perusahaan agar memberikan dampak yang positif bagi perusahaan baik dalam kualitas maupun kuantitasnya. Kinerja yang lebih tinggi mengandung arti terjadinya peningkatan efisiensi, efektifitas, atau kualitas yang lebih tinggi dari penyelesaian serangkaian tugas yang dibebankan kepada seorang karyawan dalam suatu organisasi atau perusahaan. Menurut Sedarmayanti (2011, p.260) kinerja merupakan terjemahan performance yang berarti hasil kerja seorang.

Dari hasil penilaian kinerja yang dilakukan oleh PT Sumber Trada Motor Bandar Lampung diketahui bahwa kinerja karyawan berada pada kriteria kurang baik. Hasil ini belum memenuhi harapan perusahaan dimana kriteria kinerja perusahaan paling tidak berada dalam kriteria baik. Penilaian terhadap kinerja dapat mengetahui sejauh mana karyawan itu dapat melaksanakan tugasnya dengan baik. Penilaian kinerja di PT Sumber Trada Motor Bandar Lampung dilakukan pada setiap tahunnya.

Tabel 1. Penilaian Kinerja Karyawan PT Sumber Trada Motor

\begin{tabular}{|c|c|c|c|}
\hline Divisi & Jumlah Karyawan & Nilai & Persentase \\
\hline Bengkel & 6 & 64 & 10,66 \\
\hline Sparepart & 5 & 64 & 8,88 \\
\hline Penjualan & 12 & 60 & 19,99 \\
\hline Administrasi & 7 & 70 & 13,61 \\
\hline Operator & 6 & 65 & 10,83 \\
\hline \multicolumn{2}{|c|}{ Rata-rata } & & 63,97 \\
\hline
\end{tabular}

Sumber: PT Sumber Trada Motor Tahun 2017

Berdasarkan tabel 1. terlihat bahwa hasil kinerja selama satu tahun menunjukan rata-rata target kinerja karyawan secara keseluruhan hanya mencapai 63,97 \%, dimana jika dilihat pada tabel 1 nilai tersebut memiliki kriteria nilai Kurang Baik. Kompensasi yang terjadi pada PT. Sumber Trada Motor adalah kurangnya reward ketika para karyawan yang melakukan kerja diluar jam kerja, seperti pada saat melakukan kerja lembur, dan juga perjalanan luar daerah yang dilakukan marketing untuk memasarkan produk. Selain itu fasilitas, sarana dan prasarana untuk melakukan kegiatan operasional perusahaan juga kurang maksimal sehingga semangat kerja karyawan menjadi menurun. Tidak adanya kendaraan kantor juga cukup menghambat proses pemasaran produk khususnya pada saat karyawan harus melakukan aktivitas. 


\section{METODE PENELITIAN}

Penelitian ini yang di ukur adalah variabel (X) Motivasi Kerja, dan variabel (Y) yaitu Kinerja. Uji persyaratan instrument penelitian menguji validitas dan reliabilitas. Populasi penelitian sebanyak 36 responden yang akan dibagikan kepada karyawan PT Sumber Trada Motor Bandar Lampung. Alat analisis yang digunakan dalam penelitian adalah regresi linier sederhana.

\section{HASIL DAN PEMBAHASAN}

\section{Hasil Uji Validitas}

Uji validitas dilakukan dengan menggunakan korelasi product moment. Dengan penelitian ini, uji validitas untuk menghitung data yang akan dihitung dan proses pengujiannya dilakukan dengan menggunakan aplikasi SPSS 20.

Hasil uji validitas variabel kompensasi (X) dengan menampilkan seluruh item pernyataan yang bersangkutan mengenai kompensasi. Hasil yang didapatkan yaitu nilai $r_{\text {hitung }}$ lebih besar dari $r_{\text {tabel }}(0.329)$, dimana nilai $r_{\text {hitung }}$ paling tinggi yaitu 0,881 dan paling rendah 0,470 . Dengan demikian seluruh item pernyataan kompensasi dinyatakan valid.

Hasil uji validitas variabel kinerja karyawan (Y) dengan menampilkan seluruh item pernyataan yang bersangkutan mengenai kinerja karyawan. Hasil yang didapatkan yaitu nilai $r_{\text {hitung }}$ lebih besar dari $r_{\text {tabel }}(0.329)$, dimana nilai $r_{\text {hitung }}$ paling tinggi yaitu 0,829 dan paling rendah 0,506. Dengan demikian seluruh item kinerja karyawan dinyatakan valid.

\section{Hasil Uji Reliabilitas}

Uji reliabilitas dilakukan untuk mengetahui konsistensi alat ukur dalam penggunaannya. Pada penelitian ini, uji reliabilitas dilakukan kepada 36 orang responden nilai cronbach's alpha sebesar 0,873 untuk kompensasi (X1) dengan tingkat reliabel sangat tinggi, 0,758, untuk variabel kinerja (Y) dengan tingkat reliabel sangat tinggi.

\section{Hasil Uji Multikolinieritas}

Uji mulikolinieritas dalam penelitian ini dilakukan dengan melihat nilai variance inflation factor (VIF) dengan menggunakan SPSS 20 dan diperoleh hasil sebagai berikut:

Tabel 2 Hasil Uji Multikolinieritas

\begin{tabular}{|c|c|c|}
\hline Variabel Bebas & Nilai Tolerance & Nilai VIF \% \\
\hline Kompensasi (X1) & 0,991 & 1,009 \\
\hline
\end{tabular}

Sumber : Hasil data diolah tahun 2018

Berdasarkan pada Tabel 2 sesuai dengan ketentuan uji multikolineritas, jika nilai VIF kurang dari 10 maka tidak terdapat korelasi berdasarkan tabel diatas dapat dilihat bahwa nilai VIF yaitu 1,009 kurang dari 10. Sehingga dapat disimpulkan bahwa tidak 
terdapat multikolineritas dalam data penelitian ini. Artinya bahwa antar variabel bebas Kompensasi (X) tidak saling mengganggu atau mempengaruhi).

\section{Hasil Uji Linieritas}

Kompensasi (X) Terhadap Kinerja Karyawan (Y) hasil perhitungan ANOVA didapat nilai Sig pada baris Deviantion from linierity $0,001<0,05$ atau nilai $\mathrm{F}_{\text {hitung }} 4,887$ $>F_{\text {tabel }}$ 3,28. Dengan demikian $\mathrm{Sig}<$ alpha dan $F_{\text {hitung }}>F_{\text {tabel }}$, maka Ho ditolak yang menyatakan model regresi berbentuk tidak linier.

\section{Hasil Uji Regresi Sederhana}

Tabel 3 Hasil Uji Regresi Linier Sederhana

\begin{tabular}{|c|c|}
\hline Nilai Korelasi (R) & R Square $\mathbf{( R}^{\mathbf{2}}$ ) \\
\hline 0,420 & 0,177 \\
\hline
\end{tabular}

Sumber: Hasil data diolah tahun 2018

Pada tabel 3 diperoleh nilai koefisien determinasinya (R Squares) sebesar 0,177 menunjukan bahwa Kinerja (Y) dipengaruhi Kompensasi (X) sedangkan 82,3\% di pengaruhi oleh faktor/variabel lain. Hubungan Kompensasi (X) terhadap Kinerja (Y) adalah sebesar 0,420 hasil ini menunjukan hubungan yang cukup/sedang antara variabel Kompensasi (X) terhadap Kinerja (Y).

Tabel 4 Hasil Uji Koefisien Regresi

\begin{tabular}{|l|c|c|}
\hline & B & Std.Error \\
\hline $\begin{array}{l}\text { Konstanta } \\
\text { (Kinerja) }\end{array}$ & 22,925 & 5,652 \\
\hline Kompensasi & 0,485 & 0,179 \\
\hline \multicolumn{3}{|l|}{ Sumber: Hasil data diolah tahun 2018}
\end{tabular}

Persamaan regresinya sebagai berikut :

$$
\begin{aligned}
& Y=a+b_{1} \\
& Y=22,925+0,485 X_{1}
\end{aligned}
$$

Keterangan :

$\mathrm{Y}=$ Keputusan Pembelian

a $\quad$ konstanta

$\mathrm{b} \quad=$ koefisien regresi

$\mathrm{X}_{1} \quad=$ Kompensasi

$\mathrm{X}_{2}=$ Motivasi 
Persamaan regresi di atas dapat dijelaskan sebagai berikut:

1 Konstanta sebesar 22,925 artinya jika Kompensasi (X) nilainya adalah 0, Kinerja nilainya adalah 22,925 .

2 Koefisien regresi untuk variabel Kompensasi (X) sebesar 0,485 menyatakan bahwa setiap penambahan sebesar satu satuan X (Kompensasi) maka akan menurunkan Kinerja sebesar 0,485. Koefisien bernilai positif artinya terjadi hubungan positif antara Kompensasi dengan Kinerja, semakin besar pengaruh Kompensasi maka semakin meningkat Kinerja Karyawan.

\section{Hasil Uji t}

Tabel 5 Koefisien Regresi Kompensasi (X1) dan Kinerja (Y)

\begin{tabular}{|l|c|c|}
\hline \multirow{2}{*}{ Kompensasi (X1) } & $\mathbf{t}_{\text {hitung }}$ & Sig \\
\cline { 2 - 3 } & 2,701 & 0,011 \\
\hline
\end{tabular}

Sumber : Hasil data diolah tahun 2018

Terlihat bahwa $t_{\text {hitung }}$ sebesar 2,701 sedangkan ttabel dengan dk (36-2) adalah 2,032. Jadi $t_{\text {hitung }}(2,701)>t_{\text {tabel }}(2,032)$. Dengan demikian Ho ditolak dan Ha diterima. Kesimpulannya Kompensasi berpengaruh terhadap Kinerja karyawan PT. Sumber Trada Motor Bandar Lampung.

\section{KESIMPULAN}

Berdasarkan analisis data dan tujuan penelitian pada bab sebelumnya maka dapat disimpulkan bahwa sebagai berikut: Kompensasi berpengaruh terhadap Kinerja karyawan PT Sumber Trada Motor Bandar Lampung.

\section{DAFTAR PUSTAKA}

Aprilia, Echa Siska. 2017. Pengaruh Kompensasi dan Motivasi Kerja Terhadap Kinerja Karyawan Pada Bank Syariah Mandiri. Fakultas Ekonomi dan Bisnis Islam. Uin Raden Fatah, Palembang.

Arikunto, S. 2016. Prosedur Penelitian. Pt. Rineka Cipta, Jakarta.

Bangun, Wilson. 2012. Manajemen Sumber Daya Manusia. Erlangga, Jakarta. 
Darmajaya, IIB. 2016. Panduan Penyusunan Karya Ilmiah. Jurusan Manajemen, Bandar Lampung.

Hasibuan, Malayu S.P. 2016. Manajemen Sumber Daya Manusia. PT. Bumi Aksara, Jakarta.

Oktawati, Desy. 2016. Pengaruh Kompensasi dan Motivasi Terhadap Kinerja Pegawai Pada Dinas Pendapatan Pengelolaan Keuangan dan Aset Daerah Kabupaten Sarolangun (DPPKAD). Program Pascasarjana. Universitas Terbuka, Sarolangun.

Priansa, Donni Juni. 2014. Perencanaan dan Pengembangan Sumber Daya Manusia. Alfabeta, Bandung.

Rivai, Veithzal. 2011. Manajemen Sumber Daya Manusia Untuk Perusahaan Dari Teori Ke Praktek. PT. Rajagrafindo Persada, Jakarta.

Simamora, Henry. 2004. Manajemen Sumber Daya Mnausia. STIE YKPN, Yogyakarta.

Sinambela. Lijan Poltak. 2016. Manajemen Sumber Daya Manusia. PT Bumi Aksara, Jakarta.

Sugiyono. 2010. Metode Penelitian Kuantitatif Kualitatif dan R\&D. Alfabeta, Bandung.

Sugiyono. 2016. Metode Penelitian Kuantitatif, Kualitatif, Dan R\&D. Alfabeta, Bandung.

Suwati, Yuli. 2013. Pengaruh Kompensasi dan Motivasi Kerja terhadap Kinerja Karyawan pada PT. Tunas Hijau Samarinda. Fakultas Ilmu Sosial dan Politik, Universitas Mulawarman, Samarinda.

Syahyuti. 2010. Definisi, Variabel, Indikator dan Pengukuran dalam Ilmu Sosial. Bina Rena Pariwara, Jakarta.

Wibowo. 2016. Manajemen Kinerja. PT Raja Grafindo Persada, Jakarta 